\title{
Blue Grama Vegetation Responds Inconsistently to Cholla Cactus Control'
}

\section{REX D. PIEPER}

Associate Professor of Range Science, New Mexico State University, Las Cruces.

\section{Highlight}

Walkingstick cholla cactus was removed from plots with light (328 plants/ acre), moderate (427 plants/acre) and heavy (607 plants/acre) cholla stands, and herbage production was determined on these and corresponding control plots over a four-year period. There were no significant differences between grubbed and ungrubbed for any year on any density class. However, when the data for four years were pooled, there was significantly greater production on the grubbed plots at the light and moderate cholla densities. On the plots with heavy cholla densities, herbaceous production was significantly higher on the ungrubbed plots. Lack of clear-cut response of herbaceous vegetation to cholla removal may be related to differences in early growth and in root distribution of cholla cactus and herbaceous vegetation.

Various species of cholla cactus form a conspicuous component of Southwestern vegetation from California across Arizona, New Mexico, and into Texas and from Colorado in the north to Mexico in the south. In New Mexico, walkingstick cholla (Opuntia imbricata (Haw.) DC.) is common in grassland and desert vegetation types occurring on over four million acres (Fig. 1). Livestock operators feel that cholla cactus interferes with livestock movements, reduces grass production, and lowers wool qualities. Consequently, large-scale control programs have been undertaken on many areas. Over 65,000 acres had been controlled in New Mexico by 1966.

Research in Arizona has shown large increases in density of several species of cholla on desert grassland ranges (Glendening, 1952). In New Mexico, density of walkingstick cholla has also increased in the past 50 years (Fraser, 1968). Several studies have reported changes in cholla density following various types of brush-control practices (Humphrey, 1949; Reynolds and Bohning, 1956; Cable, 1967).

\footnotetext{
${ }^{1}$ Journal article 347, Agricultural Experiment Station, New Mexico State University, Las Cruces, New Mexico, 88001. Received February 3, 1970; accepted for publication March 1, 1970.
}

However, there has been little research to determine the effects of cholla control on grass production. Ranchers and administrators of control programs need to know what effect cholla control has on herbaceous vegetation before they plan a control program. Consequently, studies to evaluate responses of blue grama vegetation to walkingstick cholla control were initiated on the Fort Stanton Cooperative Range Research Station in the spring of 1966.

\section{Materials and Methods}

The Fort Stanton Cooperative Range Research Station is located in the foothills of the Sacramento Mountains in southern Lincoln County, New Mexico. Elevations vary from about 6200 to 7500 feet. The average annual precipitation is about $15^{1 / 2}$ inches, of which just over $60 \%$ falls during June, July, August, and September. Monthly precipitation totals for the study area are presented in Table 1 . The vegetation is characterized by pinyon-juniper and oak stands on the shallow, rocky soils and open grassland areas on the deep soils.

The area selected for study was on a low ridge with a slight northeast exposure. There was a pronounced cholla density gradient from the heavy stands on the upper part of the slope to the open stands on the lower part of the slope. The area had not been grazed by domestic livestock for 17 years and was ungrazed during the study period. Plots 75 by 100 feet were established on both sides of the ridge. Cholla plants were counted in each plot. Plots with three density classes of cholla were chosen: 279-378, 410-441, and 505-680 plants per acre. These plots averaged 328 plants/acre on the light stands, 427 on moderate stands, and 607 on heavy stands. There were six plots in each density class; three plots were randomly selected in each density class for complete cholla removal and three were left as ungrubbed control. The experiment was a $2 \times 3$ factorial in a completely randomized design with 3 replications. The cholla was removed by hand-grubbing, which disturbed the surrounding vegetation only slightly, if at all. The plots were examined periodically for removal of sprouts and rooted sets.

Herbage production was determined on each plot by hand-clipping all herbaceous growth at ground level from $1 \times 2 \mathrm{ft}$ quadrats. There were 10 such quadrats randomly located in each plot. The quadrats were clipped at the end of the growing season in late September or early October. If a quadrat fell so that a stem or stump of cholla was in the quadrat, the quadrat was moved a predetermined distance and direction before it was clipped. Old growth was discarded and new growth was dried at $70 \mathrm{C}$ before being weighed.

\section{Results}

Total herbage production for all treatments and densities for the four years of the study is shown in Table 2. When the data were analyzed separately for each year, the analysis of variance showed no significant differences between treatments or among density classes, nor was the treatment $\times$ density interaction significant. However, when the data for each year were combined, the analysis of variance showed a significant difference among density classes $(P<0.05)$ 


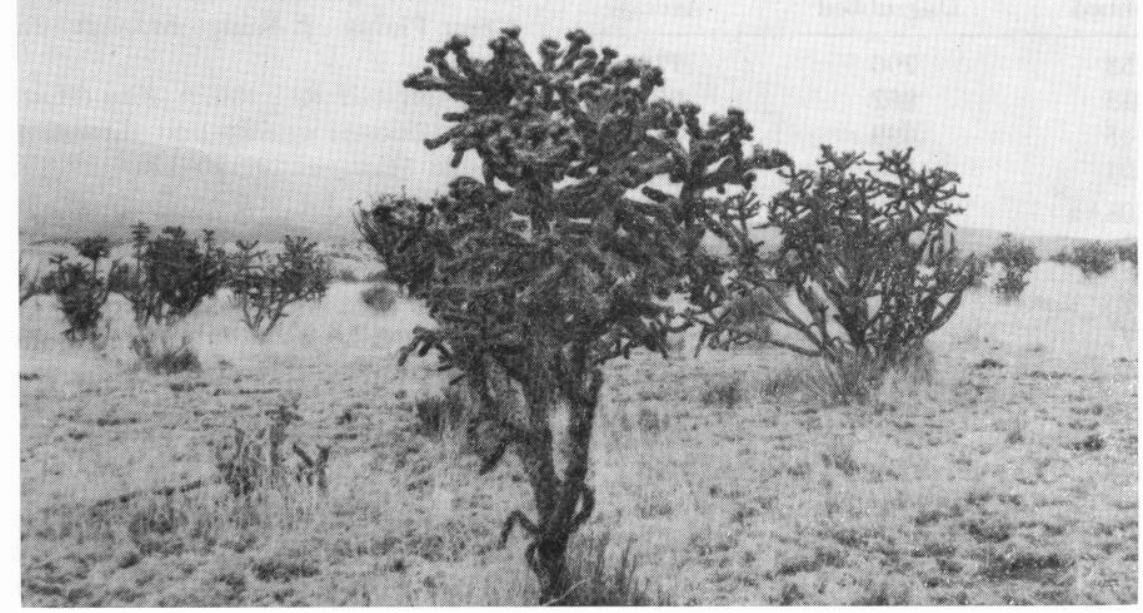

FIG. 1. Large walkingstick cholla cactus plant which is characteristic of grassland vegetation in New Mexico.

and a significant treatment $\times$ density interaction $(\mathrm{P}<0.05)$.

The significant treatment $\times$ density interaction resulted from the differential response of herbaceous vegetation on plots with a heavy cholla stand compared to those with light and moderate stands. Approximately 160 pounds per acre more herbage was produced on the grubbed plots than on the ungrubbed plots of both the light and moderate densities, but 133 pounds more herbage per acre was produced on the ungrubbed plots than on the grubbed plots of the heavy

density. These differences were consistent for all years of the study. Consequently, when herbage production was averaged on the grubbed and ungrubbed plots, there was a nonsignificant difference.

There was a nonsignificant difference in herbage production among the different density classes on the grubbed plots. However, the ungrubbed plots with a heavy cholla stand produced significantly more herbage than ungrubbed plots with light and moderate stands of cholla.

Yearly differences in herbage production appears to be related
Table 1. Monthly precipitation (inches) totals at the study site.

\begin{tabular}{lcccc}
\hline \hline & \multicolumn{4}{c}{ Total precipitation } \\
\cline { 2 - 5 } Month & $1966-67$ & $1967-68$ & $1968-69$ & $1969-70$ \\
\hline June & 1.58 & 2.00 & 0.10 & 0.62 \\
July & 2.25 & 3.39 & 2.87 & 3.87 \\
August & 0.32 & 3.76 & 2.41 & 2.40 \\
September & 6.60 & 0.43 & 0.32 & 2.83 \\
October & 0.72 & 0 & 0 & \\
November & 0.10 & 0.21 & 0.41 & \\
December & 0 & 0.85 & 0.91 & \\
January & Tr & 0.45 & 0.10 & \\
February & 0.35 & 1.12 & 0.80 & \\
March & 0.12 & 0.50 & 0.62 & \\
April & 0.20 & 0.10 & 0.85 & \\
May & 0.41 & 0 & 1.84 & \\
Totals & 12.65 & 12.81 & 11.23 & \\
\end{tabular}

to distribution of precipitation. Highest herbage yields were obtained in 1967, when precipitation was above average in June, July, and August (Table 1). However, differences in precipitation did not change the relative differences between grubbed and ungrubbed plots.

\section{Discussion}

The greater production on ungrubbed cholla plots than on grubbed plots at the high density level is difficult to explain on the basis of classical concepts of competition for soil moisture and nutrients. If cholla cactus has detrimental influences on herbaceous vegetation, these influences should be greater at heavy cholla densities than under light and moderate stands. However, data reported here do not support this hypothesis. Herbage production on the ungrubbed plots with heavy cholla densities suggests that cholla may improve microclimatic conditions for herbage production.

The lack of response of herbaceous vegetation to cholla removal at all density classes may be related to differences in growth periods and root distribution between cholla and the herbaceous vegetation. Fraser (1968) has shown that cholla begins and completes its growth earlier than the herbaceous vegetation. Dittmer (1959) found that the root system of walkingstick cholla is rather shallow. Roots of blue grama, the dominant herbaceous species on the site, extend to three feet (Coupland and Johnson, 1965). However, most blue grama root weight is concentrated in the upper 10 inches of soil (Weaver and Darland, 1949). Distribution of blue grama roots on the study area which has not been grazed for 17 years may be different from that on areas of moderate or heavy grazing. Soil moisture studies have revealed close relationships between moisture contained in branches of the cholla plant and soil moisture at the 2inch level for walkingstick cholla. Cholla branch increase apparently was independent of soil moisture. 
Table 2. Average herbage production (lb./acre ${ }^{1}$ ) on grubbed and ungrubbed plots at Fort Stanton.

\begin{tabular}{crccc}
\hline \hline $\begin{array}{c}\text { Cholla cactus } \\
\text { plants/acre }\end{array}$ & Year & Grubbed & Ungrubbed & Average \\
\hline 328 & 1966 & 753 & 796 & 775 \\
& 1967 & 1043 & 862 & 951 \\
& 1968 & 743 & 699 & 721 \\
& 1969 & 691 & 566 & 629 \\
427 & Average & $808 \mathrm{Aa}$ & $731 \mathrm{Bb}$ & $769 \mathrm{~d}$ \\
& 1966 & 896 & 867 & 882 \\
& 1967 & 1025 & 861 & 943 \\
& 1968 & 771 & 608 & 690 \\
607 & 1969 & 579 & 626 & 603 \\
& Average & $818 \mathrm{Ca}$ & $741 \mathrm{Db}$ & $780 \mathrm{~d}$ \\
& 1966 & 918 & 992 & 955 \\
& 1967 & 813 & 1048 & 931 \\
& 1968 & 728 & 897 & 813 \\
& 1969 & 744 & 800 & 772 \\
& Average & $801 \mathrm{Ea}$ & $934 \mathrm{Fc}$ & $868 \mathrm{e}$ \\
& $809 \mathrm{G}$ & $802 \mathrm{G}$ &
\end{tabular}

${ }_{1}^{1}$ Different capital letters indicate significant differences $(P<0.05)$ between means on same line while different small letters indicate significant differences $(\mathrm{P}<0.05)$ among means in the same column.

Blue grama herbage weight increase was closely related to soil moisture at 2, 6 and 14-inch depths (Fraser, 1968).

Consequently walkingstick cholla may be drawing on some soil moisture sources which are not utilized heavily by herbaceous species. Bement (1968) found similar conditions for prickly pear cactus on short grass plains in Colorado. His data showed there was no significant difference in herbage production between areas with and without prickly pear cactus.
Evaluation of cholla control does not rest entirely on response of herbaceous vegetation. There is a restriction of utilization of grass plants growing next to the cholla plant and a reluctance of livestock to graze in dense cholla stands (Martin and Tschirley, 1969). However, there are few studies reporting utilization of areas of heavy cholla infestations compared to that on control areas. Other possible benefits of cholla control include easier handling of livestock and higher wool quality on range sheep.

\section{Literature Cited}

Bement, R. E. 1968. Plains pricklypear: relation to grazing intensity and blue grama yield on Central Great Plains. J. Range Manage. 21: 83-86.

Cable, Dwight R. 1967. Fire effects on semidesert grasses and shrubs. J. Range Manage. 20:170-176.

Coupland, R. T., and R. E. Johnson. 1965. Rooting characteristics of native grassland species in Saskatchewan. J. Ecol. 53:475-507.

DitTmer, Howard J. 1959. A study of the external surface of Opuntia imbricata. Southwestern Nat. 4: 33-39.

Fraser, Joseph G. 1968. Some autecological characteristics of walkingstick cholla (Opuntia imbricata (Haw.) DC.) in New Mexico. Unpub. M.S. Thesis. New Mexico State University.

Glendening, G. E. 1952. Some quantitative data of the increase of of mesquite and cactus on a desert grassland range in southern Arizona. Ecology 39:319-328.

Humphrey, R. R. 1949. Fire as a means of controlling velvet mesquite, burroweed, and cholla on southern Arimona ranges. J. Range Manage. 2:175-182.

Martin, S. Clark, and Fred $H$. Tschirley. 1969. Changes in cactus numbers after cabling. Prog. Agr. in Ariz. 21:16-17.

Reynolds, II. G., and J. W. Bohning. 1956. Effects of burning on a desert grassshrub range in southern Arizona. Ecology 37:769-776.

Weaver, J. E., and R. W. Darland. 1949. Soil-root relationships of certain native grasses in various soil types. Ecol. Monogr. 19:303-338.

\section{Dues}

Society dues, which include an annual subscription to the Journal of Range Management and Rangeman's News, are on a calendar year basis.

1971 dues are now past due; delinquent members will be suspended in the near future. 